Proc. Estonian Acad. Sci. Biol. Ecol., 2004, 53, 4, 251-259

\title{
Environmental factors affecting the distribution of charophyte species in Estonian coastal waters, Baltic Sea
}

\author{
Kaire Torn ${ }^{\mathrm{a}, \mathrm{b}^{*}}$ and Georg Martin ${ }^{\mathrm{a}}$ \\ ${ }^{a}$ Estonian Marine Institute, University of Tartu, Mäealuse 10a, 12618 Tallinn, Estonia \\ ${ }^{\mathrm{b}}$ Institute of Botany and Ecology, University of Tartu, Lai 40, 51005 Tartu, Estonia
}

Received 6 April 2004, in revised form 3 August 2004

\begin{abstract}
Charophyte communities from 77 locations in the Estonian coastal sea were described according to their community structure and complex of environmental factors. The influence of depth, exposure, substrate quality, and salinity on the charophyte community structure was analysed. Depth turned out to be the most important structuring factor for charophyte communities while substrate quality and exposure ranked second. Salinity had no influence on the community structure within the observed interval. The most exposure tolerant species were Tolypella nidifica and Chara aspera. Chara aspera was also least selective about the substrate quality.
\end{abstract}

Key words: Charophytes, Baltic Sea, depth distribution, substrate quality, salinity, exposure.

\section{INTRODUCTION}

The distribution of benthic vegetation is influenced by a complex of ecological factors. For the Baltic Sea abiotic factors have been found to be more important than biotic ones (Kautsky, 1988; Kautsky \& van der Maarel, 1990; Martin, 2000). In the Baltic Sea charophytes mostly inhabit sheltered coastal areas where their distribution pattern is primarily controlled by exposure, sediment type, and salinity regime (Schubert \& Yousef, 2001; Torn et al., 2003). Considerable variability exists in preferences of ecological conditions between different charophyte species (Schubert \& Blindow, 2003).

Usually charophytes are able to inhabit all depth ranges within the photic zone. In clear water lakes charophytes often reach much deeper areas than do submerged angiosperms and are dominant in deeper water layers (Chambers \& Kalff, 1985),

* Corresponding author, kaire.torn@ut.ee 
but they can also be a substantial part of the vegetation in shallow fresh and brackish water. In the Baltic Sea charophytes are supposed to inhabit mostly the shallow, sheltered nearshore strip (Schubert \& Blindow, 2003).

Light is stated to be a very important environmental factor controlling the development of the charophyte population. Fluctuation in light climate can cause morphological changes and degradation of plants during their lifetime (Henricson, 2002).

The sensitivity of charophytes to high nutrient concentrations is described in the literature, but some earlier investigations showed lack of direct toxic effect of high phosphorus concentrations on plants (Forsberg, 1965). Other laboratory experiments even resulted in high growth rates of Chara spp. at high phosphorus concentrations (Henricsson, 1976; Blindow, 1988). It is shown that light not phosphorus limits the occurrence of charophytes at high nutrient concentrations (Blindow, 1992; Portielje \& Roijackers, 1995; Schwartz \& Hawes, 1997).

There is no evidence that the temperature regime has any strong influence on the structure and character of charophyte populations although several investigations show that temperature affects physiological processes of charophytes. Combined with light climate and seasonality, temperature has a complex effect on photosynthetic activity (Menendez \& Sanchez, 1998).

Most of the studies of charophyte ecology focus on freshwater conditions (Coops, 2002). Recently different aspects in charophytes ecology in brackish water have been recognized (Blindow et al., 2003; Torn et al., 2003; Kotta et al., 2004), but there are still few data available about the behaviour of these plants in brackish conditions.

The aim of the present study was to ascertain the influence of the environmental conditions such as wave action, bottom substrate, salinity, and light climate on the distribution pattern of various charophyte species in the Estonian coastal sea.

\section{MATERIAL AND METHODS}

The material for the present study was collected during the spring and summer of 2001. Study localities were chosen using all available information (sediment maps, previous records, etc.) to represent conditions most likely to suit charophyte communities (e.g. shallow soft-bottom bays and lagoons) (Fig. 1). Sampling was designed to cover as much of the Estonian coastline as possible including areas with potentially suitable habitats.

During fieldwork altogether 94 localities along the Estonian coastline were visited and descriptions from 142 sites were obtained. In certain localities different depth zones were treated as different sites. Sampling was performed by SCUBA diving from a boat (39 localities) or diving directly from the shore (55 localities). In cases of sampling from the shore, benthic communities were described to a depth of 1-2 m depending on the peculiarities of the shoreline and the depth gradient. 


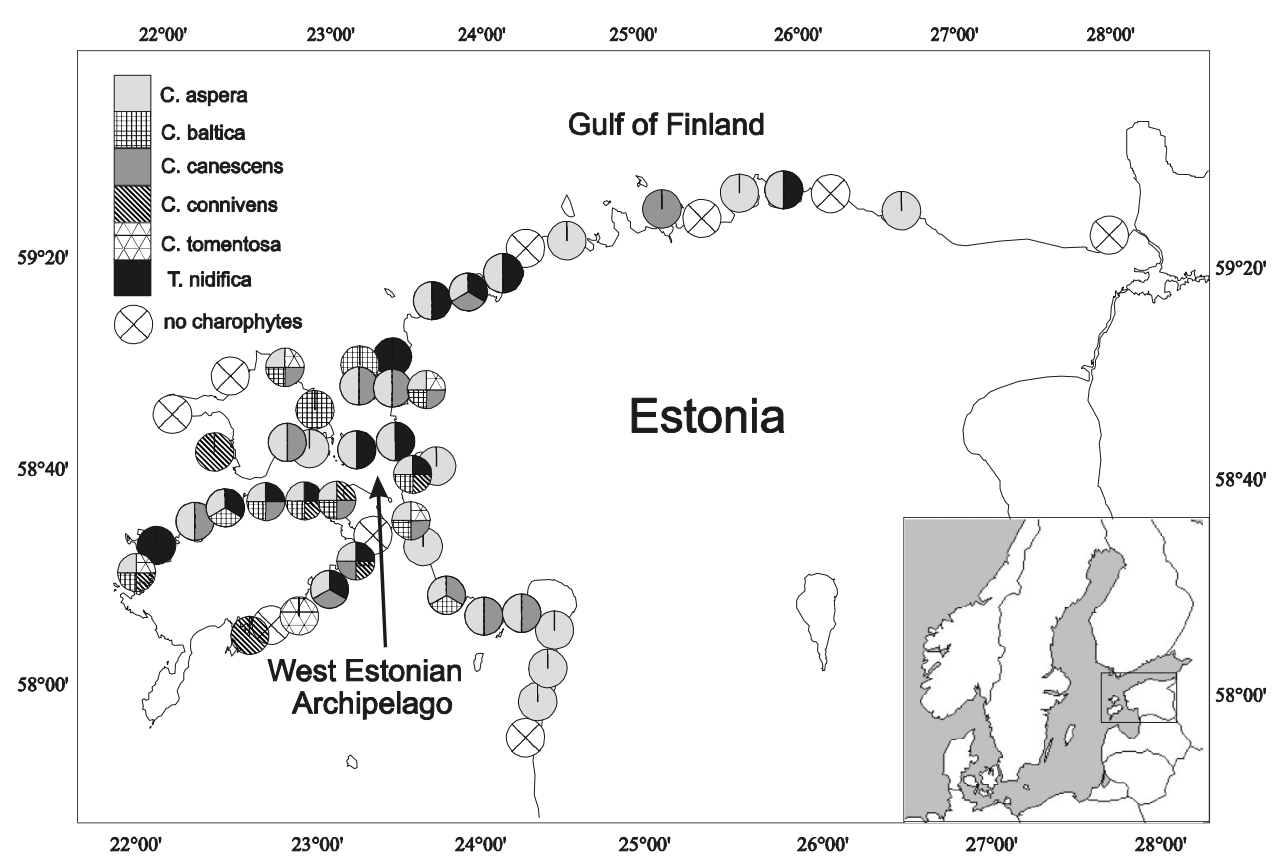

Fig. 1. Distribution of charophyte species in Estonian coastal waters in 2001. Closely situated sites are merged under a single symbol on the map.

For each locality its GPS position was recorded. The biological parameters recorded were the total coverage of benthic vegetation in each site and the coverage of different species. The environmental variables recorded were water salinity and type of substrate (see Table 1 for substrate coding).

Table 1. Bottom substrate coding (according to Kautsky, 1989)

\begin{tabular}{r|lllll}
\hline \multicolumn{1}{c}{ Code } & & & Substrates & \\
\hline 1 & Mud & & & \\
2 & Mud & Sand & & \\
3 & Clay & Sand & & \\
4 & & Sand & & & \\
5 & Mud & Sand & & Stones* & Boulder* \\
6 & & Sand & & Stones* & Boulders* \\
7 & & & Gravel & & \\
8 & Mud & Sand & & Stones & \\
9 & & Sand & Gravel & Stones & \\
10 & & Sand & & Stones & Boulders \\
11 & & & Stones & \\
12 & & & Stones & Boulders \\
13 & & & & Boulders
\end{tabular}


The wave exposure value at the sampling points was measured by the Baardseth index (Baardseth, 1970) using nautical charts with a $1: 50000$ or $1: 100000$ scale. To calculate the index, the centre of a transparent circular disc with a radius corresponding to $7.5 \mathrm{~km}$ was placed on the study site on the chart. The disc was divided into 40 sectors with the sector angle of $9^{\circ}$. The index was derived as the sum of the sectors free of islands or mainland.

The evaluation of the effect of the different environmental factors on the distribution of charophytes was performed by the Canonical Correspondence Analysis (CCA) technique (ter Braak, 1986, 1994). This analysis is unique among the ordination methods in that the ordination of the main matrix (by reciprocal averaging) is constrained by a multiple regression on environmental variables included in the second matrix. In our case the environmental variables tested were salinity, depth, bottom composition, and exposure (Baardseth index).

The nomenclature of species was given according to Nielsen et al. (1995). Historical data were obtained from literature records as well as from field diaries offered for the study by Dr. Tiiu Trei.

\section{RESULTS}

Charophyte species were present in 77 locations. Altogether occurrence of six charophyte species was described in these locations. The most frequent of them was Chara aspera (found in 55\% of all the sites). Chara baltica, C. canescens, and Tolypella nidifica were found in about $20 \%$ of the study sites. The geographical distribution of species was different. The species $C$. aspera, C. canescens, and T. nidifica were found along the whole Estonian coastline while findings of other species were restricted to waters of the West Estonian Archipelago (Fig. 1). The changes in the species distribution compared to historical data are described in Torn et al. (2003).

All sampling sites fell into the depth interval of $0-4.8 \mathrm{~m}$ and salinity range 0.64-6.63 PSU. Areas with salinity lower than 0.5 PSU were not considered in the present investigation as the main aim was to describe the charophytes from areas with brackish conditions. In most observed localities the bottom consisted of sandy substrate with mud or stone inclusions. For analysis a bottom substrate coding was created (Table 1) to reflect the "soft-hard" gradient on an analogy from Kautsky (1989).

The CCA run resulted in high correlations of the environmental variable "depth" with Axis 1 ( $\left.r_{\text {depth }}=0.821\right)$. In the observed depth range $0-4.8 \mathrm{~m}$ the depth had major influence on charophyte community parameters. Different species had slightly different depth preferences while most of the findings were concentrated to shallower locations. So T. nidifica was present in the whole depth interval while $C$. canescens was mostly found to a depth of $1.1 \mathrm{~m}$ (Table 2). The variables "exposure" and "bottom composition" had high correlations with Axis 2 $\left(r_{\text {exposure }}=0.556, r_{\text {bottom composition }}=0.555\right)$. Salinity had a minor influence on the ordination results. All the used environmental variables had a very low correlation in the original matrix, which characterized the independence of these variables. 
Table 2. Frequency of charophyte species under different environmental conditions in Estonian coastal waters

\begin{tabular}{|c|c|c|c|c|c|c|c|}
\hline & & C. aspera & C. baltica & C. canescens & C. connivens & C. tomentosa & T. nidifica \\
\hline \multirow[t]{5}{*}{ Depth, m } & $0-1$ & 47 & 10 & 19 & 10 & 3 & 19 \\
\hline & $1-2$ & 8 & 5 & 1 & 3 & 2 & 3 \\
\hline & $2-3$ & 3 & 3 & - & 2 & 2 & 1 \\
\hline & $3-4$ & - & - & - & - & - & 1 \\
\hline & $4-5$ & - & - & - & - & - & 1 \\
\hline \multirow[t]{9}{*}{ Substrate code } & 1 & 4 & 3 & 2 & 1 & 4 & - \\
\hline & 2 & 16 & 7 & 6 & 3 & 3 & - \\
\hline & 3 & 2 & - & - & 2 & - & - \\
\hline & 4 & 10 & - & 3 & - & - & 8 \\
\hline & 5 & 4 & 1 & 2 & 4 & - & 5 \\
\hline & 6 & 3 & 2 & 1 & 1 & - & 4 \\
\hline & 8 & 8 & 1 & 5 & 3 & - & 4 \\
\hline & 9 & 4 & 1 & - & 1 & - & 2 \\
\hline & 10 & 7 & 3 & 1 & - & - & 2 \\
\hline \multirow[t]{7}{*}{ Salinity, PSU } & $0.5-1$ & 1 & - & - & - & - & - \\
\hline & $1-2$ & 5 & - & 2 & - & 1 & - \\
\hline & $2-3$ & 12 & 2 & 6 & 3 & - & - \\
\hline & $3-4$ & 10 & - & 1 & 1 & - & 2 \\
\hline & $4-5$ & 13 & 6 & 5 & 4 & 4 & 4 \\
\hline & $5-6$ & 10 & 3 & 4 & 5 & - & 16 \\
\hline & $6-7$ & 7 & 7 & 2 & 2 & 2 & 3 \\
\hline \multirow[t]{20}{*}{ Baardseth index } & 0 & 13 & 7 & 4 & 4 & 6 & - \\
\hline & 1 & 3 & 1 & 3 & 1 & 1 & - \\
\hline & 2 & 5 & 1 & 2 & 2 & - & 1 \\
\hline & 3 & 8 & 4 & 2 & 3 & - & 6 \\
\hline & 4 & 4 & - & 2 & 2 & - & 1 \\
\hline & 5 & 7 & - & 2 & 2 & - & 3 \\
\hline & 6 & 4 & 2 & 1 & 1 & - & 3 \\
\hline & 7 & - & - & - & - & - & 3 \\
\hline & 8 & 1 & 1 & - & - & - & - \\
\hline & 9 & 2 & - & - & - & - & 1 \\
\hline & 10 & 1 & - & - & - & - & - \\
\hline & 11 & 1 & - & 1 & - & - & 2 \\
\hline & 12 & 1 & - & - & - & - & - \\
\hline & 13 & - & - & - & - & - & 1 \\
\hline & 14 & 3 & 1 & 1 & - & - & 1 \\
\hline & 15 & 2 & 1 & 2 & - & - & 1 \\
\hline & 16 & 1 & - & - & - & - & 1 \\
\hline & 18 & 1 & - & - & - & - & - \\
\hline & 20 & 1 & - & - & - & - & - \\
\hline & 29 & - & - & - & - & - & 1 \\
\hline
\end{tabular}


In the locations where charophytes were found the exposure index values varied from 0 to 29 on the Baardseth scale (Table 2). Charophytes were observed more often in extremely sheltered localities with Baardseth index not higher than 6. Wave exposure had less influence on $C$. aspera and $T$. nidifica, than on the other species, which preferred sheltered conditions and occurred in areas with exposure index over 5 only when hidden within a $C$. aspera community. Chara tomentosa occurred only at lowest exposure values of 0 and 1 .

For the occurrence and coverage values of single species the one-way ANOVA showed a significant influence of exposure and salinity only for C. aspera. A $100 \%$ coverage of $C$. aspera occurred until 5 on the Baardseth scale. The coverage of $C$. aspera decreased significantly with increasing wave action. For $C$. baltica a similar, though statistically not significant, relationship was recorded. The coverage of $C$. aspera decreased significantly with increasing salinity.

\section{DISCUSSION}

The distribution patterns of different charophyte species are closely linked to their requirements for environmental conditions. As a wide distribution of charophytes is observed in Estonian coastal waters and historically the distribution pattern has not significantly changed (Torn et al., 2003), the present conditions should be favourable for the development of extensive charophyte populations. At the same time considerable changes in the total algal population have been recorded from many areas around the Baltic and also from Estonian coastal waters (Kangas et al., 1982; Mäkinen et al., 1984; Rönnberg et al., 1995; Martin et al., 1996; Schramm \& Nienhuis, 1996; Martin, 2000). The difference in historical trends of other perennial algal groups in Estonian coastal waters and charophytes could be explained by the character of the habitat and differences in mechanisms of environmental forcing. Charophytes usually dominate at lower nutrient concentrations, while certain species of aquatic angiosperms have their main occurrence at much higher nutrient levels. In the case of eutrophication, a succession pattern from dominance of charophytes to dominance of aquatic angiosperms can often be described (Moss, 1989; Scheffer et al., 1992). The same pattern was recorded also for brackish waters of the Baltic (Yousef et al., 1997).

Salinity is one of the major factors limiting the geographical distribution of marine species, including macroalgae, in the Baltic Sea. In brackish water charophytes have to face substantial and irregular changes of the osmotic conditions. Charophytes maintain an osmotic potential higher than the outer osmotic pressure, as a consequence of which turgor pressure values are high (Winter \& Kirst, 1990, 1991a, 1992; Bisson \& Kirst, 1995). Because of the dependence of cell elongation on this process, effects on cell elongation rather than on cell division were shown by Winter \& Kirst (1991b) when the salinity of the environment was elevated and species were unable to acclimate their osmotic potential. In our material, however, no variability in the distribution pattern caused by salinity was observed. We can conclude that the observed salinity interval was within the ecological tolerance 
limits of the described species. The significant influence of salinity on the coverage of $C$. aspera could be explained by the indirect effect of wave exposure rather than the physiological impact of salinity itself.

As the light quality and availability are known from the literature to have the most important role in forming a suitable environment for charophytes, the dependence of charophyte community characteristics on depth in conditions of Estonian coastal waters is obvious. Different species have been reported to have different requirements but only some of them, such as $T$. nidifica, can penetrate to greater depths in the Baltic (Lakowitz, 1929; Olsen, 1944).

Substrate quality is generally one of the most important structuring environmental variables for benthic vegetation in the NE Baltic (Kautsky, 1989; Kautsky \& van der Maarel, 1990; Kiirikki, 1996; Martin, 2000). As charophytes are generally limited to soft substrates, the existence of preferences for different substrate quality within the soft substrates among the recorded species was somewhat surprising in our material. Findings of $C$. aspera on substrates of different structure showed the wide ecological amplitude of this species against environmental factors while the quantitative characteristics were linked to the proportion of the soft and the hard component in the substrate structure.

Wave exposure has, as a rule, a strong influence on the macrophyte community (Kautsky, 1989; Ruuskanen et al., 1999). Perennial algae with large thalli have to compensate the mechanical pressure of water movement one way or another. Morphologically charophytes do not have the mechanism to protect themselves against strong wave activity and therefore have their habitats with the weakest wave activity. Our material showed that exposure had a similar level of importance as substrate structure in the development of charophyte communities. The distribution pattern of charophyte species within the range of exposure values was different for different morphological groups. Chara aspera turned out to be the most exposure tolerant species. The morphology of the thalli (relatively short and strong) and the population strategy (dense, low communities) of this species favour the survival in exposed conditions. Also T. nidifica seems to withstand extreme exposure values, but it is absent in sheltered conditions. This can be explained by the usually deeper habitats of this species where the wave action does not actually reach. Chara tomentosa, on the other hand, is distributed only in extremely sheltered conditions where exposure values are 0 or 1 . This fact is due to the morphology of the plant. Chara connivens has a bit wider exposure interval but is also concentrated to more sheltered conditions (exposure values 0-6).

\section{ACKNOWLEDGEMENTS}

The present study was conducted in the framework of Estonian governmental programme No. $0182578 \mathrm{~s} 03$, and the publication was made possible with support from the Estonian Science Foundation (grants Nos 5927 and 5103). The authors wish to thank Dr. Jonne Kotta for valuable comments on the manuscript and an anonymous referee for many useful remarks. 


\section{REFERENCES}

Baardseth, E. 1970. A square scanning, two stage sampling method of estimating seaweed quantities. Rep. Norw. Inst. Seaweed Res., 33, 1-41.

Bisson, M. A. \& Kirst, G. O. 1995. Osmotic acclimation and turgor pressure regulation in algae. Naturwissenschaften, 82, 461-471.

Blindow, I. 1988. Phosphorus toxicity in Chara. Aquat. Bot., 32, 393-395.

Blindow, I. 1992. Decline of charophytes during eutrophication: comparison with angiosperms. Freshwater Biol., 28(1), 9-14.

Blindow, I., Dietrich, J., Möllmann, N. \& Schubert, H. 2003. Growth, photosynthesis and fertility of Chara aspera under different light and salinity conditions. Aquat. Bot., 76, 213-234.

Chambers, P. A. \& Kalff, J. 1985. Depth distribution and biomass of submersed aquatic macrophyte communities in relation to Secchi depth. Can. J. Fish. Aquat. Sci., 42, 701-709.

Coops, H. 2002. Ecology of charophytes: an introduction. Aquat. Bot., 72, 205-208.

Forsberg, C. 1965. Nutritional studies of Chara in axenic cultures. Physiol. Plant., 18, 275-290.

Henricson, C. 2002. The impact of abiotic disturbances on Chara tomentosa-communities. M.Sc. thesis. Department of Ecology and Systematics, University of Helsinki.

Henricsson, M. 1976. Nutritional studies of Chara globularis Thuill., Chara zeylanica Willd., and Chara haitensis Turpin. Ph.D. thesis, University of Uppsala.

Kangas, P., Autio, H., Hällfors, G., Luther, A., Neimi, Å. \& Salemaa, H. 1982. A general model of the decline of Fucus vesiculosus at Tvärminne, south coast of Finland in 1977-1981. Acta Bot. Fenn., 118, 1-27.

Kautsky, H. 1988. Factors Structuring Phytobenthic Communities in the Baltic Sea. Ph.D. thesis. University of Stockholm. Akademitryck, Edsbruk.

Kautsky, H. 1989. Quantitative Distribution of Plant and Animal Communities of the Phytobenthic Zone in the Baltic Sea. Askö Laboratory, Stockholm.

Kautsky, H. \& van der Maarel, E. 1990. Multivariate approaches to the variation in phytobenthic communities and environmental vectors in the Baltic Sea. Mar. Ecol. Prog. Ser., 60, 169-184.

Kiirikki, M. 1996. Dynamics of macroalgal vegetation in the northern Baltic Sea - evaluating the effects of weather and eutrophication. Walter and Andrée de Nottbeck Foundation Sci. Rep., 12, 1-15.

Kotta, J., Torn, K., Martin, G., Orav-Kotta, H. \& Paalme, T. 2004. Seasonal variation of invertebrate grazing on Chara connivens and C. tomentosa in Kõiguste Bay, NE Baltic Sea. Helgoland Mar. Res., 58, 71-76.

Lakowitz, K. 1929. Die Algenflora des gesamten Ostsee. R. Friedländer \& Sohn, Danzig.

Mäkinen, A., Haahtela, I., Ilvesalo, H., Lehto, J. \& Rönnberg, O. 1984. Changes in the littoral rocky shore vegetation in Seili area, SW Archipelago of Finland. Ophelia, 3, 157-166.

Martin, G. 2000. Phytobenthic communities of the Gulf of Riga and the inner sea of the WestEstonian Archipelago. Diss. Biol. Univ. Tartuensis, 64.

Martin, G., Paalme, T. \& Kukk, H. 1996. Long-term dynamics of the commercially useable Furcellaria lumbricalis-Coccotylus truncatus community in Kassari Bay, West-Estonian Archipelago, the Baltic Sea. In Baltic Coastal Fisheries - Resources and Management, pp. 121-129. Sea Fisheries Institute, Gdynia.

Menendez, M. \& Sanchez, A. 1998. Seasonal variations in P-I responses of Chara hispida L. and Potamogeton pectinatus L. from stream mediterranean ponds. Aquat. Bot., 61, 1-15.

Moss, B. 1989. Water pollution and the management of ecosystems: a case study of science and scientist. In Towards a More Exact Ecology (Grubb, P. J. \& Whittaker, J. B., eds.), pp. 401-422. Blackwell, Oxford.

Nielsen, R., Kristiansen, A., Mathiesen, L. \& Mathiesen, H. 1995. Distributional index of the benthic macroalgae of the Baltic Sea area. Acta Bot. Fenn., 155, 1-51. 
Olsen, S. 1944. Danish Charophyta. Chlorological, ecological and biological investigations. Kongel. Danske Vid. Selsk., Biol. Skr., 3, 1-240.

Portielje, R. \& Roijackers, R. M. M. 1995. Primary succession of aquatic macrophytes in experimental ditches in relation to nutrient input. Aquat. Bot., 50, 127-140.

Rönnberg, O., Lehto, J. \&. Haahtela, I. 1995. Recent changes in the occurrence of Fucus vesiculosus in the Archipelago Sea, SW Finland. Ann. Bot. Fenn., 22, 231-244.

Ruuskanen, A., Bäck, S. \& Reitalu, T. 1999. A comparison of two cartographic exposure methods using Fucus vesiculosus as an indicator. Mar. Biol., 134, 139-145.

Scheffer, M., de Redelijkheid, M. R. \& Noppert, F. 1992. Distribution and dynamics of submerged vegetation in a chain of shallow eutrophic lakes. Aquat. Bot., 42, 199-216.

Schramm, W. \& Nienhuis, P. H. (eds.) 1996. Marine Benthic Vegetation, Recent Changes and the Effects of Eutrophication. Springer, Berlin.

Schubert, H. \& Blindow, I. (eds.) 2003. Charophytes of the Baltic Sea. Baltic Mar. Biol. Publ., 19. Koeltz Scientific, Königstein.

Schubert, H. \& Yousef, M. A. M. 2001. Charophytes in the Baltic Sea - threats and conservation. Schriftenr. Landschaftspflege Naturschutz, 72, 7-8.

Schwartz, A. M. \& Hawes, I. 1997. Effects of changing water clarity on characean biomass and species composition in large oligotrophic lake. Aquat. Bot., 56, 169-181.

ter Braak, C. J. F. 1986. Canonical correspondence analysis: a new eigenvector technique for multivariate direct gradient analysis. Ecology, 67, 1167-1179.

ter Braak, C. J. F. 1994. Canonical community ordination. Part I: Basic theory and linear methods. Ecoscience, 1, 127-140.

Torn, K., Martin, G., Kukk, H. \& Trei, T. 2003. Distribution of charophyte species in Estonian coastal waters (NE Baltic Sea). Sci. Mar., 67, 3.

Winter, U. \& Kirst, G. O. 1990. Salinity response of a freshwater charophyte, Chara vulgaris. Plant Cell Environ., 13, 123-134.

Winter, U. \& Kirst, G. O. 1991a. Partial turgor pressure regulation in Chara canescens and its implications for a generalized hypothesis of salinity response in Charophytes. Bot. Acta, 104, 37-46.

Winter, U. \& Kirst, G. O. 1991b. Vacuolar sap composition during sexual reproduction and salinity stress in Charophytes. Bull. Soc. Bot. Fr., 138(1), 85-93.

Winter, U. \& Kirst, G. O. 1992. Turgor pressure regulation in Chara aspera (Charophyta): the role of sucrose accumulation in fertile and sterile plants. Phycologia, 31, 240-245.

Yousef, M. A. M., von Nordheim, H., Küster, A. \& Schubert, H. 1997. Eignung der Armleuchteralgen (Characeae) als Indikator für den Gewässerzustand der Flachwasserbereiche der Ostseeküste. Aktuelle Probleme der Meeresumwelt, 7, 173-182.

\section{Keskkonnategurite mõju mändvetikate levikule Eesti rannikumeres}

\section{Kaire Torn ja Georg Martin}

2001. aastal kogutud andmete põhjal on analüüsitud keskkonnategurite mõju mändvetikate levikule Eesti rannikumeres. Vaatlusalusteks teguriteks olid sügavus, soolsus, põhja tüüp ning piirkonna avatus. Neist suurimat mõju mändvetikate levikule avaldas sügavus, vähemal määral põhja tüüp ja piirkonna avatus. Soolsus olulist mõju ei avaldanud. 